\title{
EFEKTIVITAS PROGRAM PENGHAPUSAN 1000 JAMBAN \\ APUNG DI KECAMATAN MARTAPURA BARAT \\ KABUPATEN BANJAR PROVINSI KALIMANTAN SELATAN
}

\author{
Udaya Madjid $^{1}$, Nanda Eka Saputri² \\ ${ }^{1}$ Dosen IPDN Depdagri \\ udayamadjidsikota@gmail.com \\ ${ }^{2}$ Pegawai Negeri Sipil Pemerintah Provinsi Kalimantan Selatan \\ nandaekasaputri22@gmail.com
}

\begin{abstract}
Abstrak
Penelitian bertujuan untuk mendeskripsikan secara komprehensif serta memberikan rekomendasi dari hasil program penghapusan 1000 jamban apung ini. Penelitian ini menggunakan teori Sondang P. Siagian. Pengukuran efektivitas program ini dapat dilihat dari : Sumber Daya, Dana, sarana dan Prasarana, Kualitas dan Kuantitas serta Waktu. Penelitian ini merupakan penelitian kualitatif dengan menggunakan metode deskriptif. Teknik pengumpulan data dilakukan dengan wawancara, observasi, dan dokumentasi. Berdasarkan hasil penelitian diketahui bahwa Efektivitas Program Penghapusan 1000 Jamban Apung di Kecamatan Martapura Barat belum efektif karena masih terdapat beberapa kendala. Hal ini menyebabkan sungai yang ada di Sungai Martapura masih tercemar karena kebiasaan masyarakat Kecamatan Martapura Barat seperti Mandi, Cuci dan Kakus di Jamban Apung masih ada. Untuk itu pemerintah harus melakukan adanya sosialisasi secara terus menerus meskipun nantinya jamban apung tersebut sudah dihapuskan.
\end{abstract}

Kata Kunci : Efektivitas, Program Penghapusan 1000 Jamban Apung.

\begin{abstract}
The purpose of this study is to describe comprehensively and provide recommendations from the result of this Program of Eliminating 1000 Floating Latrines. This study uses the theory of Sondang P. Siagian. Measurement of the effectiveness of this program that could be seen from: Resources, Funds, Facilities and Infrastructure, Quality and Quantity as well as Time. This research is a qualitative research using descriptive methods. The technique of collecting data is done by interviews, observation, and documentation. Based on the results of the study, it is known that Effectiveness on the Program of Eliminating 1000 Floating Latrines in West Martapura District was not effective yet because some obstacles in its implementation. This causes Martapura's river is still polluted because habituation of West Martapura Subdistrict people for Bathing, Washing and Toileting in the Floating Latrine is still available. For that government must the ongoing socialization was given as a suggestion even though the public floating latrines had been removed.
\end{abstract}


Keywords : Effectiveness, Program of Eliminating 1000 Floating Latrines

\section{PENDAHULUAN}

Kabupaten Banjar merupakan salah satu kabupaten yang banyak dialiri sungai. Masyarakat memanfaatkan sungai tersebut untuk Mandi, Cuci dan Kakus. Melihat banyaknya wilayah yang dialiri sungai di Kabupaten Banjar maka total jamban apung yang tersebar disepanjang perbatasan Kabupaten Banjar-Kabupaten Tapin sampai Kabupaten Banjar-Kota Banjarmasin yaitu sebanyak 9000 jamban apung. Banyaknya jamban terapung ini menunjukkan kondisi sanitasi yang didaerah permukiman bantaran sungai yang buruk disepanjang aliran sungai.

Air sungai yang ada sudah tercemar dengan banyaknya bakteri yang ada disana. Tapi masih banyak masyarakat yang memanfaatkan air sungai tersebut untuk mencuci beras dan sebagainya. Sehingga ini dapat berdampak buruk bagi kesehatan masyarakat. Masalah lingkungan ini merupakan masalah yang kompleks. Tingkat kemiskinan merupakan salah satu faktor yang berperan penting dalam mempengaruhi kualitas lingkungan. Tingkat kemiskinan juga sangat berhubungan dengan rendahnya pendidikan masyarakat. Sehingga pengetahuannya tentang jamban yang sehat juga cenderung masih kurang. Hal ini dapat dilihat dari kebiasaan masyarakat yang kurang sadar lingkungan seperti mengotori dan mencemari air sungai.

Sejak dulu, masalah pembuangan tinja selalu menjadi perhatian kesehatan lingkungan. Masalah pembuangan tinja ini merupakan sumber penyebaran penyakit yang kompleks dan harus sedini mungkin diatasi. Pembuangan tinja yang tidak di sanitasi dapat menyebabkan berbagai penyakit, karena perilakunya buang air besar sembarangan maka harus segera dihentikan.

Masyarakat Kabupaten Banjar sebagian besar masih terbiasa Buang Air Besar Sembarangan (BABS) terutama ke sungai. Dapat dilihat dari masih banyaknya jamban-jamban terapung yang berada di pinggiran sungai. Dimana 1 buah jamban terapung dapat digunakan 1- 10 Kepala keluarga. Hal ini menunjukkan bahwa masyarakat belum memiliki rumah yang layak ditandai dengan tidak adanya keberadaan jamban yang sehat dirumahnya masing-masing. 
Sehingga ini membuat masyarakat untuk tetap terus menerus melakukan Mandi, Cuci dan Kakus dibantaran sungai Martapura. Ini akan mengakibatkan perilaku tersebut menjadi suatu kebiasaan yang susah untuk diubahFungsi sungai telah berubah menjadi tempat pembuangan air limbah dan sampah sehingga tercemar, dangkal dan rawan terhadap banjir serta masalah lingkungan lainnya. Air sungai pun berubah menjadi keruh dan berbau. Hal ini dikarenakan terdapatnya banyak bakteri yang terdapat disungai salah satunya adalah bakteri Escherechia Coli. Escherechia Coli merupakan bakteri yang terdapat di usus manusia dan hewan yang dikeluarkan melalui tinja. Bakteri Escherechia Coli ini salah satu penyebab bakteri yang dapat mengakibatkan diare bahkan dapat mengakibatkan infeksi usus serius yang mengakibatkan sakit perut dan demam. Selain itu penyebab penyakit yang ditularkan oleh tinja manusia antara lain : tifus, disentri, kolera, bermacam-macam cacing (gelang, kremi, tambang, pita), schistosamiasis dan sebagainya (Notoatmodjo, $2007:$ 176).

Terkait dengan hal tersebut dan sesuai dengan salah satu misi Bupati Kabupaten Banjar yaitu meningkatkan permukiman yang layak huni dan berkelanjutan, maka pada tahun 2016 dilaksanakan program penghapusan 1000 jamban apung. Program ini dilakukan pemerintah Kabupaten Banjar untuk meningkatkan layanan sanitasi kepada masyarakat dengan melakukan pengelolaan air limbah.

Metode penelitian yang digunakan dalam penelitian ini adalah jenis penelitian kualitatif melalui metode deskriptif dengan pendekatan induktif. Karena dalam penelitian ini peneliti lebih berfokus untuk menggambarkan atau mendeskripsikan peristiwa yang terjadi di lapangan secara sistematis, logis dan obyektif, benar-benar ada agar mampu memahami setiap fakta-fakta yang terjadi serta memecahkan permasalahan yang ada pada penilaian efektivitas Program Penghapusan 1000 Jamban Apung di Kecamatan Martapura Barat Kabupaten Banjar Provinsi Kalimantan Selatan.

Dalam penelitian ini, Peneliti menggunakan Purposive Sampling, Snowball Sampling, dan Incidental Sampling. Data yang dibutuhkan dalam penelitian kualitatif dapat berupa data primer dan data sekunder. Berdasarkan jenis data tersebut, maka yang menjadi sumber data dalam penelitian kualitatif dapat berupa 
orang, dokumen, kegiatan, dan tempat. Sedangkan teknik pengumpulan data yang digunakan dalam penelitian ini meliputi observasi, wawancara dan dokumentasi. Dalam penelitian ini peneliti menggunakan uji validitas data menggunakan strategi triangulasi sumber dan teknik.

\section{PEMBAHASAN}

\section{A. Efektivitas Program Penghapusan 1000 Jamban Apung di Kecamatan Martapura Barat Kabupaten Banjar Provinsi Kalimantan Selatan}

Program Penghapusan 1000 Jamban Apung telah berjalan di Kabupaten Banjar sejak tahun 2016. Peneliti mengukur efektivitas Program Penghapusan 1000 Jamban Apung dengan menggunakan konsep teori yang dikemukakan oleh Sondang P.Siagian (2015:20-21). Beberapa faktor yang dapat mempengaruhi efektivitas suatu program yaitu sumber daya, dana, sarana dan prasarana, kualitas dan kuantitas serta waktu. Berdasarkan analisis dari data yang didapatkan oleh peneliti selama melaksanakan magang dan penelitian maka diperoleh informasi mengenai faktor pendukung serta faktor penghambat yang dapat mempengaruhi efektivitas Program Penghapusan 1000 Jamban Apung. Selain itu, peneliti juga dapat memahami upaya apa saja yang telah dilakukan oleh pemerintah setempat untuk mengatasi berbagai faktor penghambat yang ada. Berikut dimensi pengukuran efektivitas oleh Sondang P. Siagian antara lain:

\section{Sumber Daya}

Mengenai sumber daya untuk program ini sudah banyak perangkat daerah yang terlibat dalam program ini dan masyarakat Kecamatan Martapura Barat pun merespon positif dan mendukung program ini. Namun pemerataan sosialisasi terhadap semua desa masih kurang karena masih ada desa yang masyarakatnya belum sadar akan pentingnya program ini.

2. Dana

Sumber dana yang digunakan masih belum mencukupi untuk program penghapusan jamban apung ini. Program penghapusan ini hanya mendanai pembuatan septictank untuk pembangunan WC Individual. Untuk biaya pembangunan bilik WC tersebut, Dinas PUPR melakukan kolaborasi dana dengan Desa. Sehingga biaya pembangunan bilik tersebut menggunakan APBDes. Hal ini 
dilakukan untuk mensiasati ketidakcukupan anggaran maka Pemerintah berkolaborasi dengan Desa untuk pembuatan WC Individual.

3. Sarana dan Prasarana

Sarana dan prasarana untuk program penghapusan 1000 jamban apung ini tidak memiliki syarat khusus sehingga siapapun bisa menghapus jamban apung ini karena hanya menggunakan alat-alat yang sederhana saja dan mudah untuk didapatkan.

4. Kualitas dan Kuantitas

Ketika penghapusan jamban apung ini dilakukan ada beberapa peningkatan yang dirasakan oleh masyarakat seperti tingkat kesehatan masyarakat itu sendiri. Hal ini dibuktikan dengan meningkatnya kualitas air ditandai dengan berkurangnya bakteri E-Coli dan data masyarakat yang mengidap berbagai penyakit akibat bakteri E-Coli ini mengalami penurunan. Namun ada beberapa kendala yang akan dihadapkan oleh pemerintah yaitu kembalinya masyarakat menggunakan jamban apung jika mereka merasakan keberatan dalam pembayaran air jika mereka berpindah dari jamban apung ke WC Individual.

5. Waktu

Penghapusan 1000 Jamban Apung ini untuk Kabupaten Banjar dapat dikategorikan cepat karena target penghapusan jamban apung sampai tahun 2019 yaitu sebanyak 833 buah. Namun realisasinya jamban apung yang telah dihapuskan sebanyak 905 buah. Akan tetapi untuk di Kecamatan Martapura Barat sendiri mengalami beberapa kendala, sehingga dari 13 desa yang baru melaksanakan penghapusan jamban apung hanya 6 desa sedangkan 7 desa belum melakukan penghapusan. Dengan total jamban apung yang telah dihapuskan yaitu sebanyak 137 unit dari target sebelumnya yaitu 254 unit. 


\section{B. Faktor Pendukung dan Penghambat Efektivitas Program Penghapusan 1000 Jamban Apung di Kecamatan Martapura Barat di Kabupaten Banjar Provinsi Kalimantan Selatan}

\section{Faktor Pendukung}

Dalam penyelenggaraan Program Penghapusan 1000 Jamban Apung di Kecamatan Martapura Barat Kabupaten Banjar Provinsi Kalimantan Selatan terdapat sejumlah faktor pendukung diantaranya,

a. Kolaborasi Dana

Dalam Program Penghapusan 1000 Jamban Apung ini karena adanya keterbatasan dana maka Dinas Pekerjaan Umum dan Penataan Ruang hanya dapat memberikan fasilitas septictank saja kepada masyarakat yang jamban apungnya akan dihapuskan. Tentunya masyarakat tidak akan mau menghapus jamban apungnya jika hanya diberikan septictank tanpa bilik. Maka dari itu Dinas Pekerjaan Umum dan Penataan Ruang mengajak Desa untuk melakukan kolaborasi dana.

Kolaborasi dana adalah kerjasama yang dilakukan Dinas Pekerjaan Umum dan Penataan Ruang dengan Desa. Sehingga untuk biaya pembangunan septictank menggunakan dana dari Dinas PUPR sedangkan biaya untuk pembangunan bilik menggunakan dana dari APBDes. Hal ini dilakukan agar pembangunan ini bisa berjalan dengan cepat.

b. Sarana dan prasarana yang sederhana

Pelaksanaan program penghapusan 1000 jamban apung ini tidak ada beberapa syarat sarana yang harus dipenuhi. Alat yang dibutuhkan hanya alat-alat sederhana saja seperti palu dan linggis. Selain itu jarak antara kecamatan Martapura Barat dengan Ibukota Kabupaten tidak terlalu jauh sehingga memudahkan kecamatan Martapura Barat ini dijangkau oleh pihak yang bersangkutan

c. Terjadinya kesesuaian dengan keinginan Gubernur Kalimantan Selatan untuk menjadikan sungai Martapura sebagai salah satu kawasan wisata susur sungai

Program Penghapusan 1000 Jamban Apung ini sejalan dengan keinginan Gubernur Kalimantan Selatan, Bapak H. Sahbirin Noor yang menginginkan Kalimantan Selatan dapat mengangkat kearifan lokalnya melalui wisata susur 
sungai. Hal ini dikarenakan wilayah Kalimantan Selatan yang sebagian besar dialiri oleh sungai. Salah satunya yaitu sungai Martapura. Tentunya dalam wisata susur sungai ini, sungai Martapura akan dilalui oleh para wisatawan. Jika di tepian sungai Martapura ini banyak terdapat jamban apung maka akan mengurangi keelokan pemandangan sungai tersebut. Sehingga jamban apung ini memang harus dihapuskan agar menjadi nilai lebih dari segi wisata.

\section{Faktor Penghambat}

Dalam penyelenggaraan Program Penghapusan 1000 Jamban Apung di Kecamatan Martapura Kabupaten Banjar Provinsi Kalimantan Selatan terdapat sejumlah faktor penghambat diantaranya,

a. Sumber Dana

Dalam Program Penghapusan 1000 Jamban Apung ini dana yang digunakan dari Dinas Pekerjaan Umum dan Penataan Ruang berasal dari dana untuk Program Pengembangan Kinerja Pengelolaan Air Minum dan Air Limbah. Hal ini terjadi karena Program Penghapusan 1000 Jamban Apung ini termasuk salah satu dari kegiatan yang dilakukan oleh program Pengembangan Kinerja Pengelolaan Air Minum dan Air Limbah. Seperti yang tercantum pada Peraturan Daerah Kabupaten Banjar Nomor 1 Tahun 2012 Tentang Pengelolaan Air Limbah.

Sedangkan untuk Program Penghapusan 1000 Jamban Apung belum ada peraturannya sendiri. Sebenarnya Dinas Pekerjaan Umum dan Penataan Ruang sudah mengajukan untuk membuat regulasi mengenai Program ini akan tetapi sampai sekarang belum ada realisasinya. Program ini pun tetap terus dilakukan karena tanpa adanya perbup yang khusus untuk program ini akan tetapi sudah menjadi kewajiban untuk mengubah sanitasi yang mana untuk mencakup capaian sanitasi ini perlu campur tangannnya pemerintah. Sanitasi merupakan salah satu kebutuhan pokok manusia dan kebutuhan ini harus berlangsung secara berkelanjutan maka dari itu kita harus menjaga kebersihan sungai.

b. Minimnya pengetahuan Kepala Desa

Dalam pelaksanaan program penghapusan 1000 Jamban Apung yang dilakukan di Kecamatan Martapura Barat hanya diikuti oleh 6 desa dari 13 desa. Sehingga masih ada 7 desa yang belum melakukan program ini hal ini dikarenakan sebelum melakukan penghapusan jamban apung kepala desa dituntut untuk 
membuat proposal pembuatan WC Individual Masyarakat terlebih dahulu. Akan tetapi karena keterbatasan pengetahuan Kepala desa mereka bingung bagaimana membuat proposal tersebut. Sehingga ini menjadi penghambat dalam pelaksanaan penghapusan jamban apung tersebut.

c. Tidak adanya data baru

Untuk menghapuskan jamban apung tersebut, terlebih dahulu yang harus dilakukan adalah membangun WC Individual untuk masyarakat yang jamban apungnya akan dihapuskan. Sebelum membangun tentu harus mengetahui terlebih dahulu jumlah jamban apun yang ada di desa tersebut berapa dan berapa jumlah kepala keluarga yang memakai 1 jamban apung tersebut. Karena tidak adanya data jumlah jamban apung dan jumlah kepala keluarga yang memakai jamban apung ini sehingga menghambat cepatnya pembuatan proposal.

Dari Dinas Pekerjaan Umum dan Penataan Ruang, mereka akan menghapus jamban apung dan membangun WC Individual sesuai dengan cepat atau tidaknya proposal yang diberikan oleh Kepala Desa kepada mereka melalui Camat Martapura Barat. Untuk Kecamatan Martapura Barat sendiri ada yang cepat mengajukan proposal dan ada yang tidak. Dibuktikan dari 13 desa, hanya 6 desa yang mengajukan proposal dengan cepat sedangkan 7 desa yang lain belum menyerahkan proposal tersebut.

d. Sosialisasi dan Pelatihan

Sosialisasi dan pelatihan terus dilakukan Pemerintah Kabupaten Banjar melalui Dinas Pekerjaan Umum dan Penataan Ruang yang mana dalam hal ini perangkat daerah yang lain juga ikut membantu sosialisasi ini agar masyarakat menjadi sadar akan pentingnya kebersihan lingkungan terkhusus kebersihan tepian sungai Martapura. Akan tetapi sosialisasi dan pelatihan yang dilaksanakan kurang merata. Hal ini dibuktikan dengan masih adanya desa yang masyarakatnya belum sadar akan pentingnya kebersihan yang mereka pikirkan hanya keuntungan dan kerugian dalam hal keuagan karena mereka takut rugi jika membayar air.

\section{Upaya yang dilakukan oleh pemerintah dalam mengatasi hambatan}

a. Membuat Regulasi

Salah satu yang dilakukan agar Program Penghapusan 1000 Jamban Apung ini mempunyai dana sendiri tidak ikut di dana Program Pengembangan Kinerja 
Pengelolaan Air Minum dan Air Limbah adalah membuat regulasi baru. Jika ada regulasi maka dana yang dihasilkanpun nantinya akan lebih banyak karena dana yang dibuat untuk penghapusan jamban apung ini hanya cukup untuk pembuatan septictank saja. Jika masyarakat hanya dibangunkan septictank saja maka mereka pasti tidak mau.

b. Melakukan Pelatihan kepada Kepala Desa

Upaya yang dilakukan selama ini untuk program penghapusan 1000 Jamban Apung ini hanya untuk menyadarkan masyarakat akan pentingnya kesehatan dan membuat masyarakat agar tidak lagi menggunakan jamban apung karena begitu banyaknya dampak buruk yang akan dihasilkan jika mereka tetap melakukan hal tersebut. Namun hal itu saja tidak cukup, ada beberapa proses yang harus dilakukan sebelum penghapusan jamban apung ini dilakukan yaitu kepala desa harus menyerahkan proposal yang menyatakan bahwa dia berminat untuk pembuatan WC Individual. Dari 13 kepala desa, ada 7 kepala desa yang belum bisa membuat proposal ini. Apalagi ditambah dengan proposal yang menyatakan kerjasama bahwa untuk pembuatan bilik menggunakan dana APBDes. Ini tentu membuat Kepala Desa semakin bingung bagaimana cara membuatnya. Ini alasaan kenapa 7 desa yang ada di Kecamatan Martapura Barat belum melaksanakan program ini. Sehingga perlu dilakukan pelatihan bagi kepala desa dalam pembuatan proposal.

c. Melengkapi Data Jumlah Jamban Apung

Salah satu penghambat yang menyebabkan keterlambatan proposal ini yaitu karena adanya ketidaklengkapan data jumlah jamban apung dan jumlah kepala keluarga yang memakai jamban apung tersebut. Menurut peneliti, Kecamatan Martapura Barat sangat memiliki data yang minim. Bahkan data kependudukan saja, yang mereka buat terakhir pada tahun 2017 saja itupun karena dipaksa. Ketika mereka tidak disuruh untuk melengkapi data lagi maka mereka pun tidak mau membuat data tersebut. Padahal data tersebut sangat penting untuk dijadika arsip Kecamatan.

d. Melakukan Sosialisasi Secara Merata

Di Kecamatan Martapura Barat, memang sudah banyak diadakan sosialisasi. Akan tetapi sosialisasi yang dilaksanakan masih belum merata. Hal ini dibuktikan dengan masih adanya desa yang belum setuju akan program 
penghapusan jamban apung ini. Maka dari itu sosialisasi saja belum cukup jika sosialisasi tersebut belum dilakukan secara merata di seluruh wilayah.

\section{KESIMPULAN}

Berdasarkan penelitian mengenai Efektivitas Program Penghapusan 1000 Jamban Apung di Kecamatan Martapura Barat Kabupaten Banjar Provinsi Kalimantan Selatan yang dilakukan oleh peneliti dalam mengkaji dan menganalisis berdasarkan data yang diperoleh di lapangan, maka peneliti menarik kesimpulan sebagai berikut :

1. Program Penghapusan 1000 Jamban Apung yang dilaksanakan di Kecamatan Martapura Barat Kabupaten Banjar Provinsi Kalimantan Selatan belum berjalan efektif jika diukur berdasarkan Teori Efektivitas oleh Sondang P. Siagian. Hal ini dikarenakan masih ada beberapa indikator yang belum terpenuhi.

2. Faktor-faktor pendukung penyelenggaraan Program Penghapusan 1000 Jamban Apung di Kecamatan Martapura Barat antara lain :

a. Kolaborasi Dana

b. Sarana dan prasarana yang sederhana

c. Terjadinya kesesuaian dengan keinginan Gubernur Kalimantan Selayan untuk menjadikan sungai Martapura sebagai salah satu kawasan wisata susur sungai.

Sedangkan faktor-faktor penghambat penyelenggaraan Program Penghapusan 1000 Jamban Apung di Kecamatan Martapura Barat antara lain :

a. Sumber Dana

b. Minimnya pengetahuan Kepala Desa

c. Tidak adanya data baru

d. Sosialisasi dan Pelatihan

3. Upaya yang dilakukan pemerintah dalam mengefektifkan penyelenggaraan Program Penghapusan 1000 Jamban Apung di Kecamatan Martapura Barat antara lain :

a. Membuat Regulasi

b. Melakukan pelatihan kepada kepala desa 
c. Melakukan sosialisasi secara merata

\section{DAFTAR PUSTAKA}

A. Buku

Afifudin dan Deni Ahmmad Saebeni. 2009. Metodologi Penelitian Kualitatif. Bandung: Pustaka Setia

Agustino, Leo. 2016. Dasar-Dasar Kebijakan Publik Edisi Revisi. Bandung: Alfabeta

Arikunto, Suharsimi. 2010. Suatu Pendekatan Praktik. Jakarta: Rineka Cipta

Creswell, John W. 2013. Research Design Methodes for the Social Sciense- 4th edition. Boston: Pearso

Hamdi, Muchlis dan Siti Ismaryati. 2014. Metodologi Penelitian Administrasi. Tangerang Selatan: Universitas Terbuka

Kothari, C.R. 2004. Research Metodology Methods and Techniques (second Revised Edition), New Delhi: Publisher For One World

MacDonald, Stuart and Headlam Nicola. 2009. Research Methods Handbook Introductory Guide to Research Methos for Social Research. Center for Local Economic Strategies

Miles, Matthew B dan Huberman, A Michael. 2007. Analisis Data Kualitatif Buku Sumber Tentang Metode-Metode Baru, Terj. Tjejep Rohindi. Jakarta: Universitas Indonesia

Moenir, H.A.S. 2006. Manajemen Pelayanan Umum Di Indonesia. Jakarta: Bumi Aksara

Ndraha, Taliziduhu. 2007. Kybernologi Sebuah Rekonstruksi Ilmu Pemerintahan. Jakarta: PT. Rineka Cipta

Neuman, Lawrence W. 2006. Social Research Methods Qualitative and Quantitative Approaches, Sixth Edition. Boston: Pearso

Rakhmat, Jalaludin. 2013. Psikologi Komunikasi. Bandung: PT. Remaja Rosda Karya

Siagian, Sondang P. 2015. Manajemen Sumber Daya Manusia. Cetakan Kedua Puluh Tiga. Jakarta: PT. Bumi Aksara

Soeparman. 2003. Pembuangan Tinja dan Limbah Cair. Jakarta: EGC 
Sugiyono. 2013. Metode Penelitian Kuantitatif Kualitatif dan R\&D. Bandung: Alfabeta

Tangkilisan, Nogi Hessel. 2005. Manjamen Publik. Jakarta: PT. Gramedia Widiasarana Indonesia

Tayibnapis, Farida Yusuf. 2008. Evaluasi Program dan instrumen Evaluasi Untuk Program Pendidikan dan Penelitian. Jakarta: Rineka Cipta

Yin, Robert K. 2011. Qualitative Research From Start To Finish. New York: The Guilford Press.

B. Peraturan Perundang - Undangan

Undang-Undang Dasar Negara Republik Indonesia Tahun 1945

Undang-Undang Republik Indonesia Nomor 9 Tahun 1995 Tentang Usaha Kecil

Undang-Undang Republik Indonesia Nomor 36 Tahun 2009 Tentang Kesehatan

Undang-Undang Republik Indonesia Nomor 1 Tahun 2011 Tentang Perumahan dan Kawasan Permukiman

Undang-Undang Republik Indonesia Nomor 23 Tahun 2014 Tentang Pemerintahan Daerah

Peraturan Daerah Kabupaten Banjar Nomor 1 Tahun 2012 Tentang Pengelolaan Air Limbah

Peraturan Bersama Mendagri\&Menkes Nomor 34 Tahun 2005 dan Nomor 1138/MENKES/PB/VIII/2005 Tentang Penyelenggaran Kabupaten/Kota Sehat

Peraturan Bupati Nomor 57 Tahun 2016 Tentang Kedudukan, Susunan Organisasi, Tugas dan Fungsi Serta Tata Kerja Dinas Pekerjaan Umum dan Penataan Ruang

Peraturan Gubernur Kalimantan Selatan Nomor 5 Tahun 2007 Tentang Peruntukan dan Baku Mutu Air Sungai

C. Penelitian/Tesis

Penelitian Dya Candra MS Putranti dan Lilis Sulistyorini, 2009, "Hubungan Antara Kepemilikan Jamban Dengan Kejadian Diare Di Desa Karangagung Kecamatan Palang Kabupaten Tuban". 
Penelitian Andias Horhoruw dan Laksmono Widagdo, 2016, "Perilaku Kepala Keluarga Dalam Menggunakan Jamban di Desa Tawiri Kecamatan Teluk Ambon Kota Ambon".

Penelitian Fera Novitry dan Rizka Agustin, 2017, "Determinan Kepemilikan Jamban Sehat di Desa Sukomulyo Martapura Palembang".

Ratna Dewi. 2017. Studi Optimasi Waktu Dan Biaya Dengan Metode Duration Cost Trade Off Pada Proyek Pembangunan Gedung (Studi Kasus: Proyek Pembangunan Gedung Rektorat Tahap II Universitas Negeri Malang). Fakultas Teknik. Universitas Muhammadiyah Yogyakarta : Yogyakarta

Penelitian Syarifuddin, 2018 “Kajian Efektivitas Program Sanitasi Total Berbasis Masyarakat Berdasarkan Karateristik Lingkungan dan Evaluasi Program di Kabupaten Banjar",

Penelitian Edi Harapan, 2019 “Penggunaan Jamban Tradisional Pada Masyarakat Transisi di Sumatera Selatan".

D. Lain - lain

Depkes RI. 2004. Syarat-syarat Jamban Sehat. Jakarta: Departemen Kesehatan RI Abudllah. 2010. Tujuh Syarat Membuat Jamban Sehat, (http://sanitasi.or.id/index.php?option=com) diakses pada tanggal 19 Oktober 2019

Dinas Pekerjaan Umum dan Perumahan Rakyat. 2016. Pengurangan Jamban Terapung di Kabupaten Banjar

Dokumen Dinas Pekerjaan Umum dan Perumahan Rakyat Tahun 2016

Dokumen Dinas Lingkungan Hidup Tahun 2019

Laporan Kinerja Instansi Pemerintah Dinas Pekerjaan Umum dan Penataan Ruang, 2018

Profil Perkembangan Kependudukan Kecamatan Martapura Barat Tahun 2017 